Revue interdisciplinaire des études canadiennes en

France

$85 \mid 2018$

Le Canada, refuge américain?

\title{
'Hell, they're your problem, not ours': Draft Dodgers, Military Deserters and Canada-United States Relations in the Vietnam War Era
}

"Nom de Dieu, c'est votre problème, pas le nôtre " : réfractaires à la conscription, déserteurs et relations américano-canadiennes pendant la Guerre du Vietnam

Luke Stewart

\section{CpenEdition}

\section{Journals}

Electronic version

URL: http://journals.openedition.org/eccs/1479

DOI: $10.4000 /$ eccs. 1479

ISSN: 2429-4667

\section{Publisher}

Association française des études canadiennes (AFEC)

\section{Printed version}

Date of publication: 31 December 2018

Number of pages: 67-96

ISSN: 0153-1700

\section{Electronic reference}

Luke Stewart, «'Hell, they're your problem, not ours': Draft Dodgers, Military Deserters and CanadaUnited States Relations in the Vietnam War Era », Études canadiennes / Canadian Studies [Online], 85 | 2018, Online since 01 December 2019, connection on 01 December 2019. URL : http:// journals.openedition.org/eccs/1479; DOI : 10.4000/eccs.1479 


\title{
'Hell, they're your problem, not ours': Draft Dodgers, Military Deserters and Canada-United States Relations in the Vietnam War Era
}

\author{
Luke STEWART \\ Sciences Po Lille
}

Despite the fact tens of thousands of United States draft dodgers and military deserters came to Canada to escape the Vietnam War, the U.S. government did not launch a formal protest to the Canadian government. "Hell, they're your problem, not ours"” explores why, for example, U.S. diplomats would criticize Sweden for accepting dodgers and deserters and not Canada. This discrepancy will be examined through a transnational perspective which takes into consideration Canada's standing in U.S. foreign policy during the Cold War in general and the Vietnam War in particular.

Bien que des dizaines de milliers d'insoumis et de déserteurs aient quitté les États-Unis pour le Canada pour éviter de combattre au Vietnam, le gouvernement américain n'a pas émis de protestation formelle à l'encontre des autorités canadiennes. Cet article, intitulé "Bon dieu, c'est votre problème, pas le nôtre", explore les raisons pour lesquelles, par exemple, les diplomates états-uniens ont critiqué la Suède pour sa politique d'accueil des insoumis et déserteurs et non le Canada. Cette contradiction sera examinée dans une perspective transnationale qui prendra en considération le rôle joué par le Canada dans la politique étrangère américaine durant la guerre froide en général et dans le contexte de la guerre du Vietnam en particulier.

Writing in Ramparts magazine in April 1967, former United States Special Forces Master Sergeant Donald Duncan captured the mood on both sides of the border concerning the growing number of U.S. citizens dodging the draft by going to Canada. Estimating that between 2,500 and 3,000 draft dodgers had already entered Canada, Duncan highlighted the Canadian government's "awkward" position regarding these American émigrés. On the one hand, he quoted the Canadian Deputy Minister of Manpower and Immigration, Tom Kent, that "there is no basis in Canadian law for denying entry to someone solely because he may be seeking to avoid compulsory military service in his homeland." The rationale behind Kent's statement lay in the fact that the extradition treaty between Canada and the United States did not include violations of compulsory military service or military offences such as being absent without leave (AWOL) or desertion. On the other hand, Duncan posited that "few doubt the existence of U.S. government pressure to slow the flow of traffic" of draft dodgers. This U.S. pressure, "implied or otherwise," came from the simple reality of U.S. economic dominance through direct investment in the manufacturing, mining and petroleum sectors and Canadian dependence on the sale of "raw materials and war materials" to the U.S. Therefore, the Canadian government found itself in a difficult position because to bow to U.S. pressure on draft dodgers 


\section{LUKE STEWART}

would only unleash a latent Canadian nationalism which naturally disdained this growing American influence in the country (DUNCAN 31).

The striking reality was that from 1965 to 1973 , the period covering American escalation and the signing of the Paris Peace Accords, there was no such pressure from the United States government. Memorandum after memorandum within the Canadian government noted the stark absence of official U.S. government protest. When Duncan was writing in April 1967, a flurry of internal communications in the Canadian Department of Manpower and Immigration and the Department of External Affairs were trying to get to the bottom of the growing phenomenon and how it would respond if queried by the United States. By the end of that year it was becoming even more apparent that U.S. military deserters, those who had already been inducted in the U.S. Armed Forces, were going absent without leave in Canada and that this would cause even greater problems than that of the draft dodgers. Nonetheless, despite a low estimate of 20,000 to 30,000 draft dodgers and 4,000 military deserters in Canada during the war, neither U.S. Presidents Lyndon Johnson and Richard Nixon nor their Secretaries of State or Defense made any formal representations to the Canadian government in public or private. ${ }^{1}$ It was not until amnesty for U.S. draft offenders and military deserters became a significant political issue during the 1972 presidential election and the signing of January 1973 Paris Peace Accords that top U.S. officials publicly commented on the war resisters. For instance, in early-1973, President Nixon told the press:

Those who deserted must pay their price, and the price is not a junket in the Peace Corps, or something like that. The price is a criminal penalty for disobeying the laws of the United States. If they want to return to the United States they must pay the penalty. If they don't want to return they are certainly welcome to stay in any country that welcomes them (JOHNSON 1973, A1; “Amnesty Rejected” 1973, 4).

As the pressure for amnesty mounted on both sides of the border, the president did not single out any country for condemnation. In fact, Nixon signaled his willingness to let the dodgers and deserters stay where they were.

\footnotetext{
${ }^{1}$ The exact number of U.S. draft dodgers and deserters in Canada during the Vietnam War era is difficult to ascertain and would be cause for wild speculation in the media on both sides of the border. Both the Canadian government and the U.S. government did not keep exact records, and scholars agree that U.S. Department of Defense's estimate of deserters and the Justice Department's estimates of draft dodgers did not encompass the total amounts. For the best independent studies, see KASINSKY 1976; BASKIR and STRAUSS 1978; BELL 1979; HAGAN 2001; JONES 2005.
} 


\section{DRAFT DODGERS, MILITARY DESERTERS AND CANADA-UNITED STATES RELATIONS}

IN THE VIETNAM WAR ERA

This article will explore the U.S. government's reaction, and Canadian governmental perceptions of a possible reaction, to draft dodgers and deserters in Canada. Moreover, I will examine if Canadian officials made its policies on the basis of these reactions or perceptions. Despite the growing body of literature on U.S. draft dodgers and deserters in Canada and of Canada-U.S. relations, there is no examination of how the U.S. government responded on a diplomatic level with Canada to the growing problem. This article will tie these threads together and demonstrate that the United States government viewed the problem globally and that in order to understand its reaction to the Canadian dimension we cannot narrowly view this within the prism of Canada-U.S. relations alone. We have to take a transnational view which incorporates U.S. national security and foreign relations with other countries in the context of the Cold War in general and the Vietnam War in particular. How the Canadian government navigated these thorny issues would become a controversial problem on both sides of the border and ultimately by May 1969 both draft dodgers and military deserters would not be barred from entering Canada as legitimate immigrants. Part of this acceptance was due to the fact there was no official protest from Washington.

From the Canadian perspective, these American war resisters became a potent symbol of Canadian nationalism and sovereignty during the Vietnam War. Various Canadian anti-draft and antiwar groups, the United Church of Canada, and other ad hoc organizations lobbied the Canadian government to adopt policies of non-discrimination at the border using nationalist discourse and framing of the draft dodger/deserter issue in terms of Canadian sovereignty over the United States. There is no doubt that Canadian officials were concerned about how the United States might respond to the presence of draft dodgers, and more specifically, to the more contentious military deserters in Canada. However, it would be wrong to argue that this was the sole terrain that officials operated on when creating policy. It is also mistaken to argue that Canadian officials responded only to nationalist calls for Canada to accept the war resisters on the basis of its independence from the U.S. These activists assumed that policy was being created to cater to the demands of the U.S. government (HAGAN 2001, 41, 49-65). Instead concerns over Canadian sovereignty always animated officials in the Departments of Manpower and Immigration, External Affairs and the Royal Canadian Mounted Police (RCMP) when coordinating on policymaking; it was just a different view of sovereignty that needs to be distinguished between government officials and Canadian nationalists. Border control, immigration policy and ensuring an obedient military are hallmarks of the modern nation-state and policing these vis-à-vis American dodgers and deserters were always done with an eye toward ensuring Canadian national security. As we shall see, 


\section{LUKE STEWART}

immigration officials and the RCMP were concerned about admitting "undesirable" dissidents into Canada and of the effect this would have on the burgeoning protest movements of the 1960s and the growing internal subversive threat. Moreover, the positive treatment of U.S. deserters was framed as sending the wrong message to soldiers in the Canadian Forces who were, or could be, punished harshly for desertion. While the threat of a possible U.S. reaction hung over the heads of Canadian officials, there was never any such protest and policy decisions were made out of a respect for Canadian sovereignty and an independent country's ability to create its own laws and regulations.

Fitting American Draft Dodgers and Military Deserters into Canada-U.S. Relations

The United States government viewed the problem of draft dodgers and military deserters seeking sanctuary in foreign countries globally. In May 1968, the Department of Defense confirmed that deserters were scattered throughout thirty different countries, including Canada, Sweden, France, Mexico, Japan, Britain, West Germany, and others. How the State Department responded depended on the country and its relations and strategic interests with the United States (FITT 1968, 6). There is a glaring disparity between how the U.S. responded, and how countries reacted, to the crisis of American deserters and draft dodgers in Canada, Sweden, and France for example. As Carl-Gustaf Scott demonstrates, once Sweden decided to grant "humanitarian" asylum to American deserters in 1968, U.S. diplomats criticized their Swedish counterparts and Swedish diplomats remained constantly concerned about the negative effects this was having on U.S.-Swedish relations. Likewise Scott observed an absence of protest by the U.S. to Canada and France and attributes this discrepancy to the fact that Sweden was a neutral country in the Cold War, gave generous benefits to the Americans, and that both the French and the Canadians "treated this matter with a much greater degree of official discretion and they kept the deserters on a much tighter leash" (SCOTT 2017, 134). As Bethany Keenan demonstrates, France was not antagonistic to U.S. deserters until the spring of 1968 when peace talks to end the Vietnam War were inaugurated in Paris and deserters participated in the May uprisings which shook the country. In this case, it was the French officials who took the initiative in containing the damage the deserters could cause in order to appear as an honest power broker to help end the war in Vietnam (KEENAN 2013, 69-75).

So bad were Swedish-U.S. relations that in January 1969 the Johnson administration recalled its ambassador. The Canadian ambassador to Sweden wrote back to Ottawa that: 


\section{DRAFT DODGERS, MILITARY DESERTERS AND CANADA-UNITED STATES RELATIONS}

IN THE VIETNAM WAR ERA

(...) the withdrawal of USA Ambassador in Stockholm to Washington for consultations has been interpreted on the Swedish side as manifestation of USA Government's irritation (over Swedish treatment of USA deserters) and it was simpler to make an example of neutral [country] than of communist or NATO country (CURRY 1969a).

The Canadian ambassador was quoted in a memorandum written specifically for Prime Minister Pierre Trudeau in anticipation that President Richard Nixon would bring up the draft dodger/deserter issue in their first meeting in March 1969. As we shall see, President Nixon did not bring up the issue despite the fact that a growing controversy was brewing in the media on both sides of the border.

Why was there such a discrepancy in reaction? After closely studying Canada-U.S. relations, Robert Bothwell concludes that "the draft dodgers were, like Canada, a problem of lesser magnitude" in the United States' foreign relations. Bothwell contended that Canada was ranked as a second-rate power by U.S. officials and that its primary importance was found not in its political relations, but in its strategic geographic proximity and especially in matters of economic trade. That draft dodgers were such a minor problem for the U.S. government was backed up by the striking dearth of correspondence on the issue by between the State Department and other U.S. government agencies and between the United States and Canada (BOTHWELL 2008, 309-312; 2007, 318).

Historian and Lester Pearson biographer John English notes that it was not draft dodgers (he excludes military deserters) who concerned U.S. President Lyndon Johnson; rather it was Pearson's calling for a bombing pause over North Vietnam at Temple University in April 1965, the Canadian attempts to seat Communist China at the United Nations, the nationalizing of the Mercantile Bank, and other official statements about U.S. policies (ENGLISH 1992, 377). In his biography of Pierre Trudeau, English does not mention draft dodgers or military deserters when discussing Vietnam, Canada-U.S. relations, or any other subject. Interestingly, neither Pearson nor Trudeau mentioned dodgers or deserters in their memoirs. This is all to demonstrate that at the top echelons of political power in both Canada and the United States, U.S. war resisters in Canada did not deserve mention. This issue was to be dealt with at the ministerial level in both countries: the Department of External Affairs, the Department of Manpower and Immigration, and the Royal Canadian Mounted Police (RCMP) in Canada and by the State Department, the Defense Department, the Federal Bureau of Investigation (FBI), the Central Intelligence Agency (CIA) and the separate armed forces intelligence branches of the Navy, Air Force, and Army. This 


\section{LUKE STEWART}

interaction would mainly play out via diplomatic channels between the State Department and the Department of External Affairs. In the case of the RCMP cooperation with the FBI and the CIA, these connections were immense and outside the scope of this article. ${ }^{2}$

There is more to the discrepancy in the U.S. reaction than Sweden being a neutral country in the Cold War, Canada being a member of NATO, or how deserters and draft dodgers would be treated in different countries. I contend that Canada played a much more significant role in U.S. national security and economic interests than any of the other countries listed as havens for U.S. war resisters. How the U.S. responded to their draft offenders and military deserters seeking sanctuary in foreign countries depended largely on that particular country's relationship to the United States in the context of the Cold War and the Vietnam War in particular.

At the end of World War Two, Canada was singled out as a vital strategic asset in U.S. global power both militarily and economically. One CIA estimate of Canada from May 1950 argued that "the security of Canada is of vital concern to the United States, and the stability of Canadian political, economic, and social life is of the highest importance." Canada was politically and ideologically aligned with the United States as well as its largest trading partner selling necessary raw materials such as uranium and iron ore as well as the more traditional staples such as nickel, asbestos, platinum and others. Moreover, Canada was home to growing U.S. direct investment, the branch plant economy, and their defence industries and military establishments were becoming increasingly interconnected. "Because of this fact," the CIA report highlights, "Canada's industrial establishment may strategically be considered as supplemental to that of the US, adding significantly to the American defense potential" ("Canada" 1950). ${ }^{3}$ In

2 There were large amounts of intelligence sharing, gathering and policing of the border between the security services of the U.S. and Canada. The Department of Defense and the Justice Department would regularly share lists of U.S. war resisters with the FBI and in turn the FBI would inform the Canadian RCMP of suspected entries into Canada. Once in Canada, the Criminal Investigations Branch (C.I.B.) of the RCMP would work with the FBI to track down the whereabouts of a draft dodger or deserter and interview them to determine if they intended on staying in Canada. Moreover, RCMP officers would regularly share information with the FBI Liaison officer at the U.S Embassy in Ottawa and make frequent visits to Langley, Virginia, to share information with the CIA. For the RCMP's division of labour and cooperation with FBI, see: KELLY 1966c; PERRY 1968. For FBI, CIA, and U.S. Army, Navy, and Air Force intelligence gathering and cooperation, see: "Extent of Cooperation" 1968, 58-60. For scholarly studies of RCMP-FBI harassment of draft dodgers and deserters in Canada, see: HAGAN 2001, 41, 141, 144; KASINSKY 1976, 214-17; PRADOS 2013, 44-45; SQUIRES 2013, 106-110, 178-184.

3 For more examples of how U.S. strategic thinkers viewed Canada, see also: "Memorandum" 1950; "Geographic Intelligence Report Appraisal" 1953. 
DRAFT DODGERS, MILITARY DESERTERS AND CANADA-UNITED STATES RELATIONS IN THE VIETNAM WAR ERA

other words, while Canada could be a middle or second-rate power on the world stage, it was partner number one when it came to supplying the U.S. empire with necessary raw materials and as an outlet for its growing direct investment.

Mitchell Sharp, former Minister of Trade and Commerce (1963-1965) and then Finance (1965-1968) under Lester Pearson and Minister of External Affairs (1968-1974) under Pierre Trudeau, remarked in his memoirs that for nearly a quarter century after 1945 the two countries shared a "so-called special relationship in economic matters." For Sharp, this meant that the United States exerted an unparalleled influence over the domestic Canadian economy and that the United States could not easily pursue protectionist policies against Canada without hurting its own economy (SHARP 1994, 178-181). ${ }^{4}$ The "special relationship" was exemplified by the creation of the North Atlantic Treaty Organization (NATO) in 1949, the Canada-United States Joint Cabinet Committee on Trade and Economic Affairs in 1953, the North American Air Defence Command (NORAD) in 1957, and the Defence Production Sharing Agreement of 1959 (renewed in 1963) which between 1959 and 1973 saw Canada sell \$3.5 billion worth of arms and equipment (RHÉAUME 2011, 223-239).

During the Vietnam War, Canada played a duplicitous role in both aiding the U.S. war effort and trying to act as a third-party negotiator to bring about an end to the war through its position on the International Control Commission (ICC) and other secret peace missions. While Prime Minister Lester Pearson controversially called for a temporary bombing pause over North Vietnam in April 1965, he did not do so for South Vietnam where the majority of the bombs fell and destruction occurred. While there would be other meek demands to end the bombing of North Vietnam throughout the remainder of the Pearson administration, Canadian weapon sales would go through the roof with sales doubling between 1964 and 1966 banking \$317.1 million. Victor Levant writes that between 1965 and 1973, the Canadian defense industry sold $\$ 2.47$ billion dollars worth of hardware, napalm, and Agent Orange to the United States. A Pentagon study revealed that between 1968 and 1974, 37.5 percent of Canadian military sales were used by the U.S. in Vietnam (LEVANT 1986, 55; REGEHR 1987, 61). When a group of University of Toronto professors challenged Pearson to place an embargo on weapons sales to the U.S., Pearson responded, referring to the "special relationship," that cooperation between Canada-U.S. defence manufacturers and procurement agencies were "both necessary and logical not only as part of collective defence but also in order to meet our own national

4 See also: MAHANT and MOUNT 1999; MUIRHEAD 2006. 


\section{LUKE STEWART}

defence commitments effectively and economically" (PEARSON 1967, 126131).

While Donald Duncan was right to point out the "awkward" position Canada found itself in vis-à-vis U.S. war resisters and the Vietnam War, as long as Canada continued to be a good quiet ally to the U.S. and kept the cross-border trade of vital resources, investment capital, and war material open, the U.S. government could tolerate draft dodgers and deserters in Canada. This was not the case for Sweden. In February 1968, the CIA produced a report entitled "Peace Movements in Foreign Countries" which noted that opposition to Vietnam was a "keystone" for the international antiwar movement and mentioned Canada as an example. The report noted that the movement's effectiveness lay in "the extent that it causes difficulties for various governments in countries that are either allied to or friendly with the US and occasionally breeds strains in their relations with the US." However, in no instance "have these difficulties caused a change in these friendly governments' policy" toward the United States. Moreover, "With regard to some Western European democracies and to certain other countries such as Japan, New Zealand, and Canada, one can generalize that the peace movements, though small, are a force to be reckoned with and embarrass the governments in their relations with the US" ("Peace Movements" 1968). U.S. draft dodgers and deserters in Canada stood to be one of those possible embarrassments.

\section{The Canadian Government Responds}

By 1966 it was common for newspaper stories to refer to Canada as a "haven" for American draft dodgers and refer to this network of individuals and groups aiding this migration as a new "underground railroad" alluding to the clandestine network helping African American slaves escape from the Southern United States to Canada. The Canadian government faced a delicate problem as its most important ally and trading partner was engaged in a hotly contested war in Southeast Asia in which the primary fighting force was composed of soldiers 18 to 26 years-old who were conscripted into military service by the Selective Service System. The Departments of Manpower and Immigration, External Affairs and the RCMP had to contend with a wide array of interconnected issues when examining this problem: immigration policy, sovereignty, Canada-U.S. relations, public opinion and the media, Canadian nationalism, cross-border intelligence cooperation between the CIA and FBI with the RCMP, growing dissent and internal subversion.

Starting in October 1965 and lasting until May 1969, the government pursued a two-track policy which distinguished between draft dodgers and military deserters in its immigration policy. In each case, the government of 
Canada was not simply bowing to pressure from the United States to enact policies it thought the Americans wished the Canadians to pursue. While no doubt acutely aware of a possible U.S. reaction, the Department of Immigration in consultation with the Department of External Affairs and the RCMP enacted an internal policy centered on Canada's sovereign right to control its borders, immigration policy and defend its own military establishment. The question of how to respond to draft dodgers first confronted the government in mid-1965 before the more controversial American military deserters started to be recognized in late-1967. The first internal government statement issued in October 1965 was precipitated by a request from the Canadian Consulate-General in Los Angeles in July for guidance on the increasing volume of U.S. citizens asking about immigrating to Canada to escape the draft. The first policy statement simply stated: "There is no basis in law for the exclusion or deportation of a person who is avoiding military service in his country of origin if he is otherwise qualified to immigrate to Canada." The short announcement, as of October 1965, mentioned that no "significant number[s] of draft dodgers are coming to Canada from the United States or that a problem is developing." Nonetheless, it was stressed that the government did "not encourage" draft dodgers to come to Canada (Appendix A 1965).

Despite the fact there was no real observable problem in the fall of 1965 , a more comprehensive statement to Canadian immigration officers both at the border and at the consular level was issued on 14 January 1966. Officially titled Operations Memorandum 117 (OM 117), the "general principles" to be followed by border officers was completed with the cooperation of officials from the Department of Immigration and External Affairs and the RCMP. While OM 117 would be revised at least five times between 1966 and 1969, this first iteration consisted of six paragraphs: five addressing the question of draft dodgers and the sixth and final paragraph dealing with active-duty soldiers. After noting the "increasing number of queries" about American draft dodgers, the memorandum sought to provide border guards with guidance for how to deal with draft-age Americans applying for landed immigrant status or entering as visitors. It is important to note that OM 117 specifically refers to U.S. citizens dodging the draft, but also contains language for the general application for individuals from other countries. "Our basic position," paragraph two lays out, "is that the question of compulsory military service is a matter to be settled between the individual and his government, in which we should not become involved." This was a significant, though subtle, revision from the October 1965 statement and one which would eventually cause much confusion. The addition of "compulsory military service" provided a more precise formulation than the previous language 


\section{LUKE STEWART}

of "avoiding military service" as this could be interpreted as covering both draft dodgers and military deserters. Specifically, OM 117 was unequivocal that draft dodgers should not be discriminated against at the border because of their status as U.S. draft offenders. When it came to military deserters, despite the fact there were no confirmed cases in January 1966, a short, final paragraph would instruct immigration officers that: "There is no objection to processing such an application if the person is to be discharged in the reasonably near future, but he will not be issued a visa or granted admission until he has submitted proof of discharge." When it came to the face-to-face, "practical application," of OM 117, border officers were not to inquire about someone's draft status and could not be used to bar someone from obtaining landed immigrant status. A person's draft status, if it became known throughout the course of the interview, could be used to find out if they were seeking a temporary escape to Canada versus someone officially applying for landed immigrant status (Appendix B 1966).

This was an internal policy directive issued by the Department of Manpower and Immigration and would not become public knowledge until the summer of 1968. While there were grumblings within the various Departments and the RCMP about the wisdom of such a policy toward draft dodgers, the line was maintained by the Ministers of Immigration and External Affairs, the Canadian Ambassador to the United States, Prime Ministers Lester Pearson and Pierre Trudeau, and lower level officials interviewed by the media on numerous occasions that draft dodgers were not to be discriminated against at the border because of the fact they were violating the United States Selective Service Act. This is what Tom Kent told Ramparts magazine in September 1966 and was subsequently quoted in Donald Duncan's April 1967 article. Kent also confirmed in his letter that military deserters would be barred from Canada unless "they had completed their service." Ultimately, Kent stated that the United States government had not yet approached Canada over the issue (KENT 1966a).

The Royal Canadian Mounted Police utilized both its Criminal Investigations Branch (C.I.B.), Security and Intelligence Branch (S.I.B.) and a network of well-placed informants to gather information on draft dodgers, deserters and their supporters. Viewing the growing number of American émigrés through the lens of national security, North American intelligence cooperation, and its Cold War anti-communist crusade, the Mounties assembled a massive thirty-seven volume collection of intelligence. The RCMP was committed to identifying those Americans who were part of, or sympathetic with, "the Communist and Trotskyist penetrated protest movement" and those who would participate in the nascent "Vietnam protest movement." Therefore, the RCMP operated through what Christabelle Sethna and Steve Hewitt call the Mountie's "red tinged prism" wherein the C.I.B. and S.I.B. would view any dissent within 


\section{DRAFT DODGERS, MILITARY DESERTERS AND CANADA-UNITED STATES RELATIONS}

IN THE VIETNAM WAR ERA

Canada as part of the broader communist-inspired movement in the West during the Cold War (KELLY 1966a and 1966b; SETHNA and HEWITT 2018, chapter 1).

By early-December 1966, Members of Parliament in the House of Commons began directing questions toward the Minister of Immigration Jean Marchand and Prime Minister Lester Pearson about U.S. draft dodgers. On 2 December, MP R.W. Prittie (NDP-Burnaby-Richmond) asked the Minister of External Affairs Paul Martin if any of the draft-age Americans had applied for political asylum as refugees in Canada. At this point, there had been no applications for political asylum (KENT 1966b). ${ }^{5}$ On 12 December, the leader of the opposition, John Diefenbaker (PC-Prince Albert), stated in the House of Commons that a "committee studying the subject of draft-dodgers" estimated that 1,500 to 3,000 had already entered Canada. Diefenbaker wanted to know the government's position on admitting the draft dodgers (DIEFENBAKER 1966, 10667; CADIEUX 1966). Internally, Tom Kent wrote to Minister Jean Marchand that he did not know where Diefenbaker got his statistics from as no such committee existed. Nonetheless, Kent did advise Marchand that the Planning Branch was regularly reporting statistical analyses of the 19-26-year-old age group emigrating from the United States. From January 1962 to July 1966, 3,838 draft-age Americans had been granted landed immigrant status. Moreover, the report for the period between January to June 1966 noted that there was "a sharp increase in the proportion of males in the 19-26 age group" entering Canada. However, Kent warned that these statistics did not provide any clarity on the actual number of U.S. citizens dodging the draft as the statistics did not cover eighteen-year-olds or those coming as visitors. Nonetheless, Kent warned the Minister, "it might not be wise at this stage to bring attention to the fact that we have been concerned about the problem to the extent of conducting a statistical survey." Moreover, Kent again clarified that there had been no official protest from the U.S. government reported to date (KENT 1966c; "Evaluation" 1966).

While the U.S. government had not made a formal protest of the Canadian government's acceptance of draft dodgers, journalists in San Jose took the opportunity to ask the new Canadian Ambassador, Albert E. Ritchie, whether Canada was a haven for draft dodgers. Speaking at the World Affairs Council,

\footnotetext{
${ }^{5}$ Canada would not sign the 1951 UN Convention on Refugees until 1969. It should be noted that in two major histories on Canadian immigration policy U.S. draft dodgers and deserters are both discussed in sections on refugee policy. This was even though no U.S. war resister during the Vietnam War era received refugee status. See: KNOWLES 1997, 214; KELLEY and TREBILCOCK 1998, 363-364.
} 


\section{LUKE STEWART}

Ritchie downplayed the numbers of Americans dodging the draft in Canada and added, as noted in OM 117, that the problem of U.S. citizens dodging the draft by going to Canada was an issue to be resolved in the United States between the individual and the government. Rufus Smith, U.S. Department of State's Director of Canadian Affairs, agreed with the Canadian ambassador that the problem was primarily one to be solved by the individual dodger and the U.S. government. Smith also maintained that the news media "had exaggerated the numbers of men fleeing across the border" (Canadian Consulate (San Francisco) 1967) ${ }^{6}$

Such a statement from a U.S. State Department official must have been comforting to the Departments of Immigration and External Affairs. Surely this would have been an excellent opportunity for a U.S. government spokesman to publicly criticize the Canadian government. Instead, Rufus Smith echoed the Canadian government's belief that the problem should be dealt with in the United States. Ultimately, there was not much the American government could do without setting off an international relations problem between Canada and other governments such as Sweden and France. Nonetheless, as 1967 progressed Canadian officials would take little comfort as the number of draft dodgers increased in tandem with the work of the aid organizations and newspaper articles documenting discrimination at the border despite the public statements and internal communications within the government.

There were few media articles or reports published by the Canadian antidraft movement that sparked an internal response within the government. The reports which did often resulted in embarrassment for the Department of Manpower and Immigration, internal reviews and reformulations of policy. One article by William Johnson entitled "Those border defenders" published in the Toronto Globe and Mail in August 1967 highlighted several cases where draftage Americans were discriminated and harassed at the border because they were either suspected of being draft dodgers or were in fact draft dodgers (JOHNSON 1967). Tom Kent expressed "some concern over the article" to his assistant and this resulted in an investigation into the allegations, an instruction sent to all Canadian immigration officers essentially repeating directions already given, and OM 117 was significantly revised for the second time. In no uncertain terms, the revision of OM 117 stated:

\footnotetext{
${ }^{6}$ The Associated Press Wire Service report, published in the Montreal Gazette, 27 January 1967, is copied verbatim in a cable from the Canadian Consulate in San Francisco to the Department of External Affairs (Ottawa), 27 January 1967. It was reported internally in the Department of Immigration that Ambassador Ritchie's remarks "accord with the facts." M.C. to Jean Marchand, 27 January 1967. Both the cable and memorandum are in RG 76, Vol. 983, File 5660-1 (Part 1), LAC.
} 


\section{DRAFT DODGERS, MILITARY DESERTERS AND CANADA-UNITED STATES RELATIONS}

IN THE VIETNAM WAR ERA

Answers given by field staff have not always been consistent with Departmental policy and some have gone beyond what was authorized by this instruction. The result has been a certain amount of embarrassment for the Department. Officers must make themselves thoroughly familiar with this instruction and adhere to it strictly. (Appendix D 1967)

Border officials were still advised not to ask about an applicant's draft status (SHEEHAN 1967; Director 1967).

One of the first articles which put the policy discrepancy between military deserters and draft dodgers into public view would be written by University of Toronto historian Kenneth McNaught in early November 1967. McNaught forced the government to clarify its position on military deserters visà-vis draft dodgers and, significantly, prompted an internal review of the legal legitimacy of the government's position. McNaught, utilizing testimonies collected from the Vancouver Committee to Aid American War Objectors (VCAAWO) and the Toronto Anti-Draft Programme (TADP), did not pull any punches. "Our policy on this question is an unpleasant mixture of hypocrisy among high officials and inadequate supervision at lower echelons," he wrote. Responding to official government statements, McNaught argued: "Since deserters and draft dodgers are bound equally by American law they obviously should be treated alike by Canada. They are not - nor is actual policy in either case consistent with our deepest traditions" (MCNAUGHT 1967).

For McNaught, and growing numbers in the Canadian anti-draft movement over the remainder of the 1960s, a government policy which ostensibly welcomed draft dodgers and barred deserters was un-Canadian. Quoting extensively from his correspondence with R.B. Curry, assistant deputy minister of Immigration, McNaught disclosed the government's reasoning for its harsher treatment of deserters. First, Canada did not recognize the "doctrine of asylum" and that even if it did, "it really has no application to citizens of friendly countries" such as a U.S. or NATO military deserter. This was because, according to the government, a refugee must be fleeing persecution not prosecution. Second, the "personal qualities" of the individual applicant mattered and depending on if they met immigration criteria, a deserter nonetheless "is a man whose chief motivation is to avoid responsibilities in his own country." McNaught took a pretty hostile view of this reasoning and maintained that the proposition on asylum by the government "is repulsive."

Ultimately, McNaught saw the heavy hand of Washington over Canadian policy and urged Canadians, in their centennial year, that they "should 


\section{LUKE STEWART}

demand the firmest assurance that there will be no more subtle areas of discretion in which we oblige Washington while subverting our own traditions" (Ibid). While this was a powerful argument and one which would resonate even more widely in early 1969, there was no heavy hand of Washington influencing Canadian policy. McNaught first queried the Department of Immigration on its deserter policy in the summer of 1967 and as is clear from the assistant deputy minister's response, they did not have it worked out. In response to McNaught's article, an internal review was launched to get legal clarification.

A week after McNaught's article was published, Tom Kent wrote a letter to Marcel Cadieux, Under-Secretary of State for the Department of External Affairs, that his department is "becoming increasingly concerned about the problems arising from the admission into Canada of deserters" from the United States. Specifically, "public opinion is developing in a way that would make any deportation of a deserter highly controversial." Prophetically, Kent argued that while the number of deserters in Canada was a small number, seventy-five according to Kenneth McNaught, they would continue to grow as the war in Vietnam escalated and became more polarizing. Recounting that draft dodgers were admitted if they met immigration requirements; the deserters caused a much "more difficult problem." The main issue was "there is nothing in our law that makes a deserter as such a prohibited person." Instead of putting his department's concerns within the framework of negative consequences in the Canada-U.S. relationship, Kent instead focused on the fact that these potential landed immigrants, and possible one-day Canadian citizens, would face a situation whereby they would be at "risk of severe penalties" if they returned to the United States. Secondly, Kent contrasted the reception of deserters from the United States armed forces with how soldiers who desert the Canadian armed forces are treated. In the case of the Canadian deserter they are "subject to heavy penalties." Despite these foregoing concerns, Kent believed that under the current Immigration Points System, adopted in the fall of 1967, a military deserter would not likely be admitted anyway because they would not secure the number of points needed (50 out of 100). Regardless, the government could not count on this as a safety measure and Kent sought out the opinion of the Department of External Affairs and stated at some point it would be necessary to "explore the views of the United States." Kent stressed "the problem is not that we should be concerned to exclude deserters but that the United States, if it is really concerned, should provide means to prevent such persons leaving the country." In other words, it was not that the Canadian government should seek to bar deserters to appease the United States, but that Canada could suggest to the U.S. that they should take active measures to stop the problem in the first place and appease Canada (KENT 1967). 


\section{The United States' Response}

By May 1968, the powerful Senate Armed Services Committee (SASC) held two-days of hearings with representatives from the Departments of State and Defense on the growing crisis of active-duty GI's going AWOL or deserting to foreign countries such as Canada, Sweden, France, and Germany. The Senators were bewildered by the fact that the Defense Department and the Department of State were not more active in trying to stem the growing crisis of desertion in the military. In particular, the committee could not understand how deserters to foreign countries were not punished more heavily, especially those who made statements against the war. The Defense Department, represented by the Assistant Secretary of Defense Alfred Fitt and various military officers, submitted extensive statistics on the absentee and desertion problem as well as how the intelligence branches of the Army, Navy and Air Forces gathered and shared information. As for the Department of State, the committee was surprised by the lack of effort to communicate to Sweden or Canada that the United States was more than displeased and request the return of these soldiers. Frederick Smith, Jr., Deputy Administrator of the Bureau of Security and Consular Affairs at the State Department, provided great insight into the government's handling of the situation and is revealing for the lack of protest by the U.S. government to Canada.

In Mr. Smith's prepared remarks, he flatly laid out for the Senators that the U.S. government did not have any "legal basis under extradition treaties for demanding the return of deserters, nor is there any prospect that we could negotiate such a treaty." The reason that military desertion or any other military offence was not included in extradition treaties was because of a universal belief that such military crimes were to be placed on par with cases of political asylum. In other words, this was a political question which could result in undue problems between two countries. Moreover, under the NATO Status of Forces Agreements (SOFA) between the United States and Canada or France, U.S. soldiers who desert must be on "official duty in the country concerned." In the case of Canada, the U.S. deserters were coming from the United States and were not stationed in Canada. The same was true of France where the soldiers escaped from their bases in Germany. Nonetheless, the State Department did inform the various embassies and consulates with the names of the known deserters so that they were not issued passports. Ultimately, according to the State Department, "this approach to the problem is dictated largely by the legal limitations on our actions in the foreign country, we believe that, in the circumstances, it is the soundest one from the view of our overall national interest" (SMITH 1968, 40-41). 


\section{LUKE STEWART}

Responding to a question about when U.S. diplomats did contact their foreign counterparts about deserters, Mr. Smith stated that it "varied from country to country." With respect to Sweden, "on several different occasions and at several different levels" U.S. officials had made "informal representations" to their Swedish counterparts that the U.S. wished to have the deserters returned to the United States. In the case of France, it was French diplomats who approached their American counterparts to inform them in 1967 that the deserters would be treated as if they were any other immigrant (this would change in 1968) (Ibid 4142). One exchange is worth quoting at length:

Senator Inouye: In listening to your testimony, I gather the impression that the Department of State is not making any serious efforts to effect the return of these absentees. I get the impression that it would be better to just let things take their natural course, because of the Department's desire not to rock the boat, or to bring about a squabble, as you say here. Is my impression correct?

Mr. Smith: I would say that our position is, first, we have no legal basis in most of these situations for demanding the return of these individuals. Secondly, the governments concerned have made it quite clear to us what their position is as to these individuals. That is that they are not going to turn them over to us, and that, at least at this stage, they are going to permit them to remain in their country. This, of course, results from the situation in that country. They have their own internal political problems, and I would say in general our feeling is that it serves no useful purpose for us to make protests which usually just result in getting their backs up more over these individuals (Ibid 49-50).

With respect to Canada, Mr. Smith downplayed the seriousness of the situation. "There has been a great deal of publicity in Canada with respect to draft dodgers, but our people have seen virtually none with respect to military deserters" (Ibid 54). In response, the Canadian Embassy in Washington cabled Marcel Cadieux in Ottawa that they were trying to obtain a copy of the testimony and analyze the statistics provided to the Armed Services Committee (Canadian Embassy - Washington 1968a).

Just days after these hearings, the Toronto Daily Star published an interview with General Lewis B. Hershey, director of the Selective Service System, about the ongoing draft dodger controversy. Paraphrasing Gen. Hershey, the interviewer writes that the small number of draft dodgers in Canada were "not worth straining Canadian-American relations" over. Taking the contemporary high-end estimate of 10,000, Hershey argued that "ten thousand is not a large part of my 35 million registrants." Hershey felt this number was probably 


\section{DRAFT DODGERS, MILITARY DESERTERS AND CANADA-UNITED STATES RELATIONS} IN THE VIETNAM WAR ERA

"exaggerated" anyway and dismissed those dodging to Canada as "misfits" and "low-lifers." "Hell, they're your problem, not ours," he exclaimed. He added that if draft dodgers wanted to return to the United States and in turn entered the armed forces upon arrival they would not be prosecuted. By contrast, if a draft dodger returned to the United States and continued to refuse conscription they would be put on the top of the list for induction as a "delinquent" of which there were about 19,395 (REGULY 1968).

If the U.S. government wanted to make public or private complaints known to Canadian government officials, they had ample opportunity to do so by 1968. In fact, Gen. Hershey and the State Department by August 1968 had gone out of their way to accommodate the Canadian position and were simply downplaying the potential seriousness of the issue. It appears that Canadian Embassy officials in Washington were in contact with Rufus Smith, U.S. Department of State Director for Canadian Relations, and Gen. Lewis B. Hershey. In one case in August 1968, Col. Frank Kossa gave a speech in which he estimated there were 15,000 draft dodgers entering Canada annually. In response Smith told Canadian officials the "speech was off-the-cuff" and there was "no change whatsoever in USA policy on this subject." Furthermore, in response to the Colonel's speech, Gen. Hershey and Smith prepared a press statement which read in part:

Draft evasion is not/not an extraditable offense under our extradition treaties with Canada or, indeed, under any extradition treaty we have with any country. The Canadian government, of course, applies Canadian immigration laws and regulations when screening persons who seek to enter Canada. The Canadian government has scrupulously avoided any action which could be interpreted as encouraging persons to go to Canada for the purpose of evading USA laws. We have made no/no representations to the Canadian government on this matter and do not/not contemplate undertaking any" (Canadian Embassy - Washington. 1968b). ${ }^{7}$

When Richard Nixon won the presidency it was not clear to Canadian government officials in what new direction the administration would take the country and there were several ongoing irritants which could affect the bilateral relationship, such as the growing balance-of-payments deficit teetering in Canada's favour due to the 1965 Auto Pact, rumblings of Canada recognizing Communist China, and plans for Canada to reduce its NATO footprint in Europe.

\footnotetext{
${ }^{7}$ Many of the words in the press release were abbreviated to fit in the cable. I have decided to expand the words in the interest of readability.
} 


\section{LUKE STEWART}

Nixon had not yet announced his plan of Vietnamization in which the United States would steadily withdraw troops from Vietnam whilst secretly bombing Cambodia and Laos and increasing the bombing of South and North Vietnam.

The winter and spring of 1969 proved to be a stressful period for the new Minister of Immigration Allan MacEachen and his advisers on the draft dodger and deserter file. There was a cascade of media reports documenting discrimination at the border for U.S. deserters and a growing campaign directed at lobbying the government to open the border to deserters. During this time, the Department of Manpower and Immigration initiated a study to review its policies on draft dodgers and deserters and MacEachen was personally making moves to propose a new Immigration Regulation to ban deserters outright as immigrants to Canada. Awaiting the report, External Affairs had an interest in the direction of the study because the issue "is a potential [emphasis added] source of irritation in Canada-U.S.A. relations" (Under-Secretary of State, 1969). The issue had not yet become a diplomatic problem for Canada, but with the inauguration of President Nixon no one could be sure what was going to happen.

In preparation for Prime Minister Pierre Trudeau's first visit to Washington and meeting with President Nixon, Department of Immigration officials prepared a memorandum in anticipation that the subject would come up between the two leaders. After defining the issue and the differences between draft dodgers and military deserters, the memorandum noted: "While Canada's acceptance of deserters is likely a source of irritation to the United States, no formal protest has been received from that country" (CURRY 1969a). Responding to questions at the National Press Club in Washington, the prime minister stated on 25 March 1969:

Our policy as to deserters is not as clear as that regarding draft evaders. In general we do have statistics on this and in general Canadian policy has been, shall we say, a little less free towards deserters than to draft evaders on the basis that Immigration does consider whether a perspective immigrant has any moral or legal commitments in their country of origin (TRUDEAU 1969).

When Trudeau was not asked about the draft dodger and deserter issue by Richard Nixon in their private meeting and his statement to the press registered no comment from other governmental officials, it appeared that Washington was not very concerned about the issue.

During the preparations for Trudeau's visit to Washington, Minister MacEachen submitted a proposal to the Cabinet that an Immigration Regulation 
be implemented to exclude military deserters as possible immigrants to Canada. The final memorandum which was submitted to Cabinet was a much revised version making the argument succinctly that the status of draft dodgers should remain unchanged but that acceptance of active-duty soldiers should be rejected. While the official memorandum reflects the spirit of previous drafts, a 12 March draft version includes strong language which would be ultimately removed: "To grant asylum to deserters as refugees would constitute a blanket condemnation of the United States and its political and judicial systems." MacEachen criticized supporters of deserters as giving "comfort" to the "enemies" of the United States (Memorandum to Cabinet 1969a). This unambiguous language took a dim view of the activists challenging the government's policy of discrimination at the border. Nonetheless, while this point was softened in the official memorandum, it was not the only reason expressed for banning deserters as immigrants. Specifically, allowing such immigrants would send the wrong signal to deserters within the Canadian Armed Forces and this would also put Canada at odds with policies of other "friendly countries who usually ensure that deserters are returned to their own authorities" (Memorandum to Cabinet 1969b).

Nonetheless, Trudeau's cabinet was divided on the need for a new regulation. It was felt that this was not the right time to adopt an outright ban of deserters, that the youth of Canada overwhelming supported American draft dodgers and deserters and such a policy would hurt the Liberal Party politically. There was also a belief amongst the Ministers that the war in Vietnam was going to end soon and therefore so would the draft dodger and deserter problem (CURRY 1969b; COUILLARD 1969; DYMOND 1969). Ultimately we do not know for sure why, or who, intervened and quashed MacEachen's proposal, but for these above mentioned reasons, coupled with the fact the United States was not taking a stand on deserters with Canadian officials, the Minister of Immigration was forced to concede on 22 May 1969. "Membership in the armed service of another country, or desertion," Minister MacEachen announced in Parliament, "will not be a factor in determining the eligibility of persons applying for landed immigrant status in Canada" (MACEACHEN 1969, 8930). This was a dramatic victory for the resister aid groups and once the news spread south of the border, Vietnam war resisters flocked to Canada. Between April and August, the number of draft-aged Americans migrating north tripled each month (HAGAN 2001, 35-37). There was no official protest recorded by either the Department of External Affairs or Immigration.

It was not until amnesty for draft evaders, draft dodgers and military deserters became a campaign issue in the 1972 presidential election that high ranking government officials found the need to speak publicly about the problem. 


\section{LUKE STEWART}

President Nixon confused observers over the course of 1972 with his views on amnesty, first telling an interviewer at CBS on 2 January that he would be "very liberal with regard to amnesty." Nixon heavily qualified his remarks, making amnesty conditional on conclusion of the war, the return of all U.S. prisoners of war (P.O.W.), and those dodgers and deserters "paying the price" for breaking the law ("Views Vary Widely on Granting Amnesty" 1972, 18). This left many observers with the belief that Nixon was at least open to the idea of amnesty for war resisters. In the weeks leading up to election day, Nixon hardened his stance by closing the door to amnesty. Speaking before the National League of Families of American Prisoners and Missing in Southeast Asia on 16 October, Nixon stated "it would be the most immoral thing I could think of to give amnesty to draft dodgers and those who deserted." He compared "those who deserted America" to the Vietnam veterans, POWs, and missing in action who served their country (MUNRO 1972, 12). In even clearer terms, Nixon declared in a radio address: "there will be no amnesty for draft dodgers and deserters after the war. The few hundred who refused to serve or who deserter their country must pay a penalty for their choice." Seeking a more nuanced approach, his Vice President Spiro Agnew told the ABC television program "Issues and Answers" that it would be possible to provide a conditional amnesty based on "some kind of service" to the country (CRENSHAW 1972, A1; SUDERS 1972, E1; MASON 2004, 185). In no instance during the campaign did a high level official publicly attack Canada for its policy on deserters or draft dodgers.

After Nixon won a landslide re-election in November 1972 and the hostilities ended between the United States/Republic of Vietnam and the Democratic Republic of Vietnam/Provisional Revolutionary Government (or the National Liberation Front) in January 1973, the Nixon administration continued to argue against granting amnesty to draft dodgers and deserters. With the war over, however, the calls for amnesty grew louder and the issue was increasingly framed as a moral choice by both sides. In one instance, an emotional Secretary of Defense William Rogers addressed the amnesty issue during a lengthy press conference by arguing: "When some fled or deserted, someone had to take their place. Someone had to die. We had 46,000 battle casualties. We can't forget those who lost their lives" ("Rogers, Near Tears" 1973, A21).

In response to the Secretary of Defense's press conference, the Canadian Ambassador to the United States, Marcel Cadieux, wrote to External Affairs in Ottawa about the prospects for amnesty and how this would affect Canadian immigration policy which was undergoing stricter revisions. Anticipating "the potential for emotional exchanges and continuing ideological controversy" over the dodger and deserter controversy, Cadieux sought input from Ottawa. "The amnesty issue will for some time, I think, agitate public feeling," Cadieux wrote, 
and Americans would be closely watching what the Canadians would do. Before the election campaign of 1972, Cadieux expressed his belief that Canadian diplomats "were making progress in explaining [the] Canadian government position" in the United States and he hoped "that the current revival of interest and controversy will not/not set us back again" (CADIEUX 1973). Luckily for the war resisters and the Canadian government, Watergate and the resignation of Spiro Agnew would remove the thin veneer of morality coming from official Nixon administration pronouncements on amnesty.

By August 1974, President Nixon was forced to resign in the aftermath of the disclosure of his audio recordings implicating the president in a cover-up of Watergate. President Gerald Ford announced at the Veterans of Foreign Wars (VFW) convention in Chicago shortly after assuming office that he was advising his staff to study the question of amnesty for Vietnam War draft offenders and deserters. He told the crowd he sought "the restoration of the essential unity of Americans, within which honest differences of opinion do no descend to angry discord, and mutual problems are not polarized by excessive passion" (Ford quoted in BASKIR and STRAUSS 1978, 212). Part of this "binding of the nation's wounds" included a controversial pardon of former President Richard Nixon on 8 September 1974. Eight days later, the president publicly announced the Ford Clemency Program (FCP) for draft offenders and deserters. On the same day, Ford hosted a bipartisan congressional delegation at the White House to discuss the clemency program to the dismay of the Republican attendees. Representative Felix Hébert (R-LA), Chairman of the House Armed Services Committee, told the president he was "violently opposed and so are most of the people" and that Ford was "setting up a precedent for future crises." Senator Strom Thurmond (R-SC) argued, referring to draft offenders and deserters, that there was "no worse crime than this. This is setting a dangerous precedent" ("Henry Kissinger Memorandum of Conversation" 1974). Facing such opposition from his own party, the president allowed the clemency board to finish its work. The controversy eventually subsided as Americans moved on to a process of forgetting and the new Canadians could take a sigh of relief.

\section{Conclusion}

Given that the United States' national security and its war making ability in Vietnam were not structurally affected by the draft dodgers and deserters, it appears policymakers were not interested in making this a significant bilateral issue. While the numbers of draft dodgers and military deserters increased, the U.S. armed forces and the Selective Service System continued to draw from a large pool of draft-aged Americans. Moreover, despite the criticisms, the 


\section{LUKE STEWART}

governments of Lester Pearson and Pierre Trudeau were vehemently opposed to cancelling the Defence Production Sharing Agreements. Canada maintained its growing trade with the U.S. of vital resources necessary for the American economy. One CIA intelligence memorandum from 1971 demonstrated that "USCanadian trade grew rapidly during 1966-1970," outpacing growth in trade with Europe. In 1970, the U.S. purchased sixty-six percent of Canadian exports and supplied seventy-one percent of Canada's imports. For example, from 1960 to 1970 Canadian exports in minerals grew thirteen percent, oil and gas grew twenty-one percent, and overall exports grew fourteen percent annually. The Agency estimated that due to direct investment, Americans controlled about forty-five percent of assets in the manufacturing sector, fifty percent of oil and gas, and fifty-one percent in mining and smelting. Commenting on the growing nationalist fervor, the growing trade deficit tilting in Canada's favour, and Canada searching for export markets in Europe and Japan, the CIA nonetheless concluded: "US-Canadian economic relations are likely to remain very close in the foreseeable future, despite new friction points which will surely develop from time to time." Moreover, "the problems that beset our bilateral relations are unlikely to lead to a major confrontation" and the CIA was skeptical of Canadian attempts to search for new markets. This prediction would ultimately come to pass after the failure of the so-called Third Option ("Canada's Changing Economic Relations With the United States" 1971).

This is not to suggest that the US war resisters in Canada had no effect on Canada or the United States or that their actions were not significant in and of themselves. These war resisters were part of a much larger and multifaceted antiwar movement which would significantly disrupt both Canadian and American society. However, at a strategically high level, as long as the war resisters escaping to Canada could be contained, the United States had much larger concerns. What would have happened had the U.S. officially protested or if Canada did place an embargo on military sales and strategic raw materials we can only speculate on the possible repercussions to Canada-U.S. relations. However, there was not much the United States could do legally, as Tom Kent pointed out to Ramparts, and the U.S. State Department subsequently confirmed to Congress that draft and military offences were not included in the Canada-U.S. extradition treaty. Stuck with this reality, U.S. officials beat up on Sweden while they quietly reassured their Canadian counterparts. 
DRAFT DODGERS, MILITARY DESERTERS AND CANADA-UNITED STATES RELATIONS

IN THE VIETNAM WAR ERA

\section{Bibliography}

\section{Primary Sources}

Appendix A. 26 October 1965. In "Draft Dodgers - Instructions to Field Staffs." November 1967. RG 76, Vol. 983, File 5660-1 (Part 2), Library and Archives Canada (Hereafter LAC).

Appendix B. 14 January 1966. Operations Memorandum 117. In "Draft Dodgers - Instructions to Field Staffs." November 1967. RG 76, Vol. 983, File 5660-1 (Part 2), LAC.

Appendix D. Revised September 1967. Operations Memorandum 117. In "Draft Dodgers - Instructions to Field Staffs.” November 1967. RG 76, Vol. 983, File 5660-1 (Part 2), LAC.

“Amnesty Rejected.” Globe and Mail, 1 February 1973.

“Canada." 5 May 1950. SR-49. CIA Intelligence Analysis (Document No. CIARDP78-01617A001700050001-7), CIA General Records Collection, CIA Records Search Tool (hereafter CREST), National Archives at College Park, Maryland, USA (hereafter NACP).

"Canada's Changing Economic Relations with the United States." June 1971. CIA Intelligence Memorandum, ER IL 71-115. Document No. CIARDP85T00875R001700010067-6), CIA General Records Collection, CREST, NACP.

Canadian Consulate (San Francisco). To the Department of External Affairs (Ottawa). 27 January 1967. RG 76, Vol. 983, File 5660-1 (Part 1), LAC.

Canadian Embassy - Washington. 1968a. To Marcel Cadieux. 31 May 1968. RG 146 RCMP File, Volume 18, Correspondence 8-5-68 to 20-6-68, LAC, Access to Information Request (ATIP) No. A201500081.

Canadian Embassy - Washington. 1968b. To External Affairs. 8 August 1968. RG 146 RCMP File, Volume 21, Correspondence 7-8-68 to 28-8-68, LAC, ATIP No. A201500081.

CADIEUX Marcel. 13 December 1966. To Lester Pearson. RG 76, Vol. 983, File 5660-1 (Part 1), LAC. 


\section{LUKE STEWART}

CADIEUX Marcel. 23 February 1973. To External Affairs Ottawa. RG 146 RCMP File, Volume 36, Correspondence 27-3-71 to 17-9-74, LAC, ATIP No. A201500081.

COUILLARD L.E. 22 April 1969. To Allan MacEachen. RG 76, Vol. 983, File 5660-1(Part 5), LAC.

CRENSHAW, Albert B. 1972. "No Amnesty, Nixon Vows." Washington Post, 30 October 1972.

CURRY R.B. 1969a. Letter to Under-Secretary of State for External Affairs. 13 March 1969. RG 76, Vol. 983, File 5660-1 (Part 5), LAC.

CURRY R.B. 1969b. Letter to Deputy Minister of Immigration. 15 April 1969. RG 76, Vol. 983, File 5660-1(Part 5), LAC.

DIEFENBAKER, John. 2 December 1966. Statement. Hansard. House of Commons Debates, 27th Parliament, 1st Session, Vol. 10.

Director (Planning Branch) to Director (Home Branch), Director (Foreign Branch), and Assistant Director (Information Service, Immigration). 16 August 1967. RG 76, Vol. 983, File 5660-1 (Part 1), LAC.

DUNCAN, Donald. 1967. "Sanctuary.” Ramparts (April): 29-33.

DYMOND W.R. 15 April 1969. To L.E. Couillard. RG 76, Vol. 983, File 56601(Part 5), LAC.

"Evaluation and Co-ordination Unit to Director of Planning Branch (Immigration)." 7 October 1966. RG 76, Vol. 983, File 5660-1 (Part 1), LAC.

"Extent of Cooperation between All DOD Elements and State, Justice, FBI, and CIA." 22 May 1968. Military deserters: hearings before a subcommittee of the Committee on Armed Services, United States Senate, Ninetieth Congress, second session on the problem of deserters from military service, May 21 and 22, 1968. Washington: United States Government Printing Office.

FITT Alfred B. 21 May 1968. Testimony. Military deserters: hearings before a subcommittee of the Committee on Armed Services, United States Senate, Ninetieth Congress, second session on the problem of deserters from military service, May 21 and 22, 1968. Washington: United States Government Printing Office.

"Geographic Intelligence Report Appraisal of Special-Subject Maps of Canada." October 1953. Geographic Intelligence Report. CIA/RR-GR-28. Document No. 
DRAFT DODGERS, MILITARY DESERTERS AND CANADA-UNITED STATES RELATIONS

IN THE VIETNAM WAR ERA

CIA-RDP79-01009A000400050002-1. CIA General Records Collection, CREST, NACP.

"Henry Kissinger Memorandum of Conversation." 16 September 1974. Box 5, National Security Adviser's Memoranda of Conversation Collection - Ford Administration, Gerald R. Ford Presidential Library.

JOHNSON, Haynes. 1973. "Peace Fires Amnesty Issue: End of War Brings Troubling Questions of Amnesty.” Washington Post, 4 February 1973.

JOHNSON, William. 1967. "Those border defenders." Toronto Globe and Mail, 5 August 1967. Contained in RG 76, Vol. 983, File 5660-1 (Part 1), LAC.

KELLY W.H. 1966a. Circular memorandum. 15 July 1966. RG 146, RCMP File, Volume 3, Correspondence 27-6-66 to 15-7-66, LAC, ATIP No. A201500081.

KELLY W.H. 1966b. Circular memorandum. 22 August 1966. RG 146, RCMP File, Volume 5, Correspondence 13-8-66 to 31-8-66, LAC, ATIP No. A201500081.

KELLY W.H. 1966c. Circular memorandum. 22 September 1966. RG 146, RCMP File, Volume 6, Correspondence 1-9-66 to 14-10-66, LAC, ATIP No. A201500081.

KENT, Tom. 1966a. To Sol Stern. 26 September 1966, RG 76, Vol. 983, File 5660-1 (Part 2), LAC.

KENT, Tom. 1966b. To Jean Marchand. 7 December 1966, RG 76, Vol. 983, File 5660-1 (Part 1), LAC.

KENT, Tom. 1966c. To Jean Marchand. 13 December 1966, RG 76, Vol. 983, File 5660-1 (Part 1), LAC.

KENT, Tom. 1967. To Marcel Cadieux. 17 November 1967, RG 76, Vol. 983, File 5660-1 (Part 1), LAC.

MACEACHEN, Allan. 22 May 1969. Statement. Hansard. House of Commons Debates, 28th Parliament, 1st Session, Volume 8.

M.C. to Jean Marchand. 27 January 1967. RG 76, Vol. 983, File 5660-1 (Part 1), LAC. 


\section{LUKE STEWART}

MCNAUGHT, Kenneth. 1967. "After the draft dodgers: American Deserters and why we should let them in, too." Star Weekly, 6-12 November 1967. Contained in RG 76, Vol. 983, File 5660-1 (Part 2), LAC.

"Memorandum by the Deputy Director of the Office of British Commonwealth and Northern European Affairs (Satterthwaite) to the Deputy Assistant Secretary of State for European Affairs" (Thompson). 8 February 1950. Reproduced in Petersen Neal et al., ed. 1977. Foreign Relations of the United States, 1950, National Security Affairs; Foreign Economic Policy, Volume I. Washington: United States Government Printing Office.

Memorandum to Cabinet. 1969a. Draft. "Admission to Canada of Draft Dodgers and Military Deserters.” 12 March 1969. RG 76, Vol. 983, File 5660-1 (Part 5), LAC.

Memorandum to Cabinet. 1969b. "Admission to Canada of Draft Dodgers and Military Deserters.” 18 March 1969. RG 76, Vol. 983, File 5660-1 (Part 5), LAC.

MUNRO, Ross H. "Nixon hardens line on draft dodgers." The Globe and Mail, 17 October 1972. 12.

"Peace Movements in Foreign Countries." CIA Report. 14 February 1968. Document No. CIA-RDP70B00338R000200050094-8). CIA General Records Collection. CREST, NACP.

PEARSON Lester. 10 March 1967. Address to Faculty Committee on Vietnam. University of Toronto. Reproduced in Blanchette Arthur E., ed. 1980. Canadian Foreign Policy, 1966-1976: Selected Speeches and Documents, Ottawa: Gage Publishing Limited.

PERRY W.F.G. 7 October 1968. Letter to Departmental Secretary. RG146, RCMP File, Volume 22, Correspondence 29-8-68 to 18-10-68, LAC, ATIP No. A201500081.

REGULY, Robert. 1968. "Mr. Conscription: Those draft-dodgers "misfits, lowlifers," Toronto Daily Star, 24 May 1968. RG 146 RCMP File, Volume 18, Correspondence 8-5-68 to 20-6-68, LAC, ATIP No. A201500081.

“Rogers, Near Tears, Scores War Evaders.” Washington Post, 16 February 1973.

SHEEHAN T.B. to A.D.M. 11 August 1967. RG 76, Vol. 983, File 5660-1 (Part 1), LAC. 
DRAFT DODGERS, MILITARY DESERTERS AND CANADA-UNITED STATES RELATIONS

IN THE VIETNAM WAR ERA

SMITH Frederick, Jr. 22 May 1968. Testimony. Military deserters: hearings before a subcommittee of the Committee on Armed Services, United States Senate, Ninetieth Congress, second session on the problem of deserters from military service, May 21 and 22, 1968. Washington: United States Government Printing Office.

SUDERS, Donald.1972. "Nixon, McGovern Differ Sharply on Top Campaign Issues.” Washington Post, 2 November 1972.

TRUDEAU, Pierre. 25 March 1969. Press Conference at National Press Club, Washington, D.C. Canadian Broadcasting Corporations Digital Archives. Accessed 28 August 2018. https://www.cbc.ca/archives/entry/trudeauswashington-press-club-speech

Under-Secretary of State for External Affairs to Deputy Minister (Immigration). 3 February 1969. RG 76, Vol. 983, File 5660-1 (Part 5), LAC.

“Views Vary Widely on Granting Amnesty.” Hartford Courant, 15 October 1972.

\section{Secondary Sources}

AZZI, Stephen. 2015. Reconcilable Differences: A History of Canada-US Relations. Oxford: Oxford University Press.

BASKIR, Lawrence M. and William A. STRAUSS. 1978. Chance and Circumstance: the Draft, the War, and the Vietnam Generation. New York: Knopf.

BELL, D. Bruce. 1979. Characteristics of Army Deserters in the DOD Special Discharge Review Program. October. Alexandria: U.S. Army Research Institute for the Behavioral and Social Sciences.

BOTHWELL, Robert. 2007. Alliance and Illusion: Canada and the World, 1945 1984. Vancouver: University of British Columbia Press.

BOTHWELL, Robert. 1992. Canada and the United States: The Politics of Partnership, Toronto: University of Toronto Press.

BOTHWELL, Robert. 2008. "Thanks for the Fish: Nixon, Kissinger, and Canada," in Nixon in the World: American Foreign Relations, 1969-1977, eds. Fredrik Logevall and Andrew Preston. Oxford: Oxford University Press.

BOTHWELL, Robert. 2015. Your Country, My Country: A Unified History of the United States and Canada. Oxford: Oxford University Press. 


\section{LUKE STEWART}

CHURCHILL, David S. 2004. “An Ambiguous Welcome: Vietnam Draft Resistance, the Canadian State and Cold War Containment," Histoire Sociale/Social History 37, no.7: 1-26.

CHURCHILL, David S. 2012). "Draft Resisters, Left Nationalism, and the Politics of Anti-Imperialism," The Canadian Historical Review 93, no.2 (June): 227-60.

ENGLISH, John. 1992. The Worldly Years: The Life of Lester Pearson Volume II, 1949-1972. Toronto: Alfred A. Knopf Canada.

GRANATSTEIN, J.L. 1996. Yankee Go Home: Canadians and AntiAmericanism. Toronto: HarperCollins Publishers Ltd.

HAGAN, John. 2001. Northern Passage: American Vietnam War Resisters in Canada. Cambridge, Harvard University Press.

HILLMER, Norman and J.L. Granatstein. 1991., For Better or Worse: Canada and the United States. Toronto, Copp Clark Pitman Ltd.

JONES, Joseph. 2005. Contending Statistics: The Numbers for U.S. Vietnam War Resisters in Canada. Vancouver: Quarter Sheaf.

JONES, Joseph. 2008. Happenstance and Misquotation. Vancouver: Quarter Sheaf.

KASINSKY, Renée. 1976. Refugees from Militarism: Draft-Age Americans in Canada. New Brunswick: Transaction Books.

KEENAN, Bethany S. 2013. “'At the crossroads of world attitudes and reaction': the Paris American Committee to Stopwar and American anti-war activism in France, 1966-1968." Journal of Transatlantic Studies 11, no.1: 69-75.

KELLEY, Kinette and Michael TREBILCOCK. 1998. The Making of the Mosaic: A History of Canadian Immigration Policy. Toronto: University of Toronto Press.

KNOWLES, Valerie. 1997. Strangers at Our Gates: Canadian Immigration and Immigration Policy, 1540-1997. Toronto: Dundurn Press.

LEVANT, Victor. 1986. Quiet Complicity: Canadian Involvement in the Vietnam War. Toronto: Between the Lines Press.

MAHANT, Edelgard and Graeme S. MOUNT. 1999. Invisible and Inaudible in Washington: American Policies Toward Canada. Vancouver: UBC Press. 
DRAFT DODGERS, MILITARY DESERTERS AND CANADA-UNITED STATES RELATIONS

IN THE VIETNAM WAR ERA

MARTIN, Lawrence. 1982. The presidents and the prime ministers: Washington and Ottawa face to face: the myth of bilateral bliss, 1867-1982. Toronto: Doubleday Canada.

MASON, Robert. 2004. Richard Nixon and the Quest for a New Majority. Chapel Hill: The University of North Carolina Press.

MAXWELL, Donald W. 2006. "Religion and Politics at the Border: Canadian Church Support for American Vietnam War Resisters." Journal of Church and State 48: 807-829.

MAXWELL, Donald W. 201. "These Are the Things You Gain If You Make Our Country Your Country': US-Vietnam War Draft Resisters and Military Deserters and the Meaning of Citizenship in North America in the 1970s," Peace \& Change 40, no. 4:437-461.

MUIRHEAD, Bruce. 2006. Dancing around the elephant: creating a prosperous Canada in an era of American dominance, 1957-1973. Toronto: University of Toronto Press.

PRADOS, John. 2013. The Family Jewels: The CIA, Secrecy and the President. Austin: University of Texas Press.

REGEHR, Ernie. 1987. Arms Canada: The Deadly Business of Military Exports. Toronto: James Lorimer \& Company.

RHÉAUME, Charles. 2011. "Cautious neighbour policy: Canada's helping hand in winding down the Vietnam War," Cold War History 11, no.2 (May): 223-239.

RODGERS, Kathleen. 2014. Welcome to Resisterville: American Dissidents in British Columbia. Vancouver: UBC Press.

SCOTT, Carl-Gustaf. 2017. Swedish Social Democracy and the Vietnam War. Huddinge: Södertörns högskola.

SETHNAN Christabelle and Steve HEWITT. 2018. Just Watch Us: RCMP Surveillance of the Women's Liberation Movement in Cold War Canada. Montreal: McGill-Queen's University Press.

SHARP, Mitchell. 1994. Which Reminds Me ... A Memoir. Toronto: University of Toronto Press.

SQUIRES, Jessica. 2013. Building Sanctuary: The Movement to Support Vietnam War Resisters in Canada, 1965-73. Vancouver: UBC Press. 


\section{LUKE STEWART}

THOMPSON, John Herd and Stephen RANDALL. 2008. Canada and the United States: Ambivalent Allies. $4^{\text {th }}$ edition. Athens: The University of Georgia Press.

YOUNG, Jay. 2011. "Defining a Community in Exile: Vietnam War Resister Communication and Identity in AMEX, 1968-1973." Histoire sociale/Social history 44, no. 1: 115-146. 